\title{
ЗНАКОВІСТЬ АФОРИСТИКИ Б. Д. ГРІНЧЕНКА: ПЕРЕТИН МОВНОГО І НАЦІОНАЛЬНОГО КОДІВ
}

Шарманова Н. М. Знаковість афористики Б. Д. Грінченка: перетин мовного і національного кодів.

У статті акцентовано на семіотиці афоризму, здійснено опис індивідуальноавторських висловів Б. Д. Грінченка в контексті нових напрямів дослідження мовної царини - лінгвокультурологічного, прагмалінгвістичного, антропологічних засад лінгвостилістики. Висвітлено теоретичні питання й прикладні аспекти афористики в межах пареміологічної концепції, розширено відомості про основні підходи до лінгвістичної ідентифікації цих мовних одиниць. Узагальнено комплекс семантичних явищ, що лежать в основі структурного моделювання афоризмів, досліджено зв'язки між їхньою семантикою, стилістичними особливостями i прагматичним спрямуванням в ідіолекті Б. Д. Грінченка.

Ключові слова: афоризм, антропоцентричний підхід, семіотика, мовний код, 
коди культури.

Шарманова Н. Н. Знаковость афористики Б. Д. Гринченко: взаимодействие языкового и национального кодов.

В статье сделан акцент на семиотике афоризма, проведено описание индивидуально-авторских выражений Б. Д. Гринченко в контексте новых направлений исследования языка - лингвокультурологического, прагмалингвистического, антропологических основ лингвостилистики. Раскрываются теоретические и прикладные вопросы афористики в аспекте паремиологической концепции, расширены сведения об основных подходах к лингвистической идентификации этих единиц языка. Обобщен комплекс семантических явлений, лежащих в основе структурного моделирования афоризмов, исследована взаимосвязь между их семантикой, стилистическими особенностями и прагматической направленностью в идиолекте Б. Д. Гринченко.

Ключевые слова: афоризм, антропоцентрический подход, семиотика, код языка, код культуры.

Sharmanova N. M. Semiotic of B. D. Hrynchenko's aphorisms: language and national culture interconnection.

The article focuses on the semiotic, linguistic and cultural identification of B. D. Hrynchenko's aphorisms in the context of new approaches in linguistic studies linguaculturological, pragmalinguistic and anthropological. The article also deals with the theoretical and practical aspects of aphorisms in the paremiological conception and gives additional information on the main approaches in the linguistic identification of these units. The article generalizes the complex of linguistic phenomena that are in the basis of structural modelling of aphorisms, researches the connections in their meanings, stylistic peculiarities and pragmatic direction in the idiolect of B. D. Hrynchenko.

Key words: aphorism, anthropological approach, semiotic, language cod, culture cod.

Серед сучасних наукових підходів до вивчення мовної царини варто акцентувати на антропоцентричному їх спрямуванні, що відбиває безпосередній зв'язок мовних явищ із лінгвокультурними. Такі тенденції пояснюються тим, що на сьогодні більшість парадигм мовознавчих знань має антропологічне підгрунтя, зокрема й лінгвостилістичні студії, які розкривають стилістичні процеси, актуальні для сучасної україномовної практики в різних сферах суспільного вжитку. Антропоцентричні засади в галузі лінгвістики найбільш виразно розкривають дослідження мовного доробку тих постатей, які стали знаковими, епохальними для української нації. Адже «пізнання мовної особистості, ідіолекту здійснюється шляхом аналізу насамперед текстів, у яких реалізована мовна діяльність носія ідіолекту, та моделювання мовного довкілля, яке впливало (могло впливати) на досліджуване індивідуальне мовлення та формування рис тексту» [2, с. 16]. 
Досить цінним надбанням у лінгвостилістичному контексті $є$ афористика, яка водночас кристалізує мовний портрет письменника при продукуванні індивідуально-авторських висловів і постає невичерпним джерелом для дослідження духовного потенціалу українського етносу, розуміння його менталітету. Афористика як феномен духовної культури нації формує концептосферу національної мови і репрезентує систему цінностей та ідеалів соціуму, виступає засобом конденсації образно-логічної думки, у якій «відбито й актуалізовано основні життєві цінності нашого народу» [5, с. 31].

В афоризмах крізь призму авторських інтенцій відбивається вся національно-культурна концептосфера, у якій закодовані уявлення етносу про Всесвіт, і зокрема український світ як перетин двох площин - кодів мовної царини із системою кодів вітчизняної культури. Кодом називають систему умовних знаків, правил передачі інформації каналами зв'язку (комунікації) відповідно до їхніх технічних, соціально-культурних особливостей і функцій [1, с. 73].

Код як засіб певної ідіоетнічної мови є базовим семіотичним терміном та одним із центральних понять лінгвокультурологічної наукової парадигми. Ф. С. Бацевич дає таке визначення мовного коду: це «сукупність засобів мови, що використовуються у комунікації і характеризуються певною однорідністю» [1, с. 76]. Відповідність між планом змісту і планом вираження знака якраз і втілює код, який задає значущість знака, що має бути розшифрована. Культурно-мовний код, застосовуваний у комунікації, становить єдність мовних і культурних знань, які втілюються у вербальних повідомленнях [там же, с. 75].

Кодом номінують систему образів, яка належить до певної культурної сфери або ж артефакти культури, що виступають у знаковій функції (Ю. М. Лотман). Важливі для культури смисли можуть виражатися засобами різноманітних кодів, кожний із яких репрезентує свою структуралізацію й концептуалізацію певного конкретного смислу (С. М. Толстая). Система культурних кодів $€$ підгрунтям надгрупової спільноти, використовує різні символи для самоідентифікації (Т. Б. Щепанська).

Культурний код являє собою систему знаків матеріального й духовного світу, транслює основні національні світоглядні орієнтири, культурну спадщину того чи того народу. Ф. С. Бацевич, услід за російською дослідницею В.В.Красних, у «Словнику термінів міжкультурної комунікації» осмислює різні підходи до розуміння цього лінгвокультурологічного поняття: «1. Спосіб, яким конкретна 
культура членує, категоризує, структурує, оцінює світ, що оточує членів певної національної лінгвокультурної спільноти; “сітка”, яку культура “накидає” на навколишню дійсність. К. к. (коди культури H. Ш.) співвідносяться 3 древніми уявленнями людини. К. к. формують систему координат, котра містить і відтворює еталони культури 2. Сукупність знаків (символів), смислів та їхніх комбінацій, котрі наявні у будь-якому предметі культури певної національної лінгвокультурної спільноти. Знаходить вияв також у етнічній мові, мовній картині світу» [1, с. 74].

Афоризм виступає як усталена словесна формула, клішовані одиниця, в основу якої покладено мовний концепт, що грунтується на універсальних й етнічних символах. Кожний письменник по-своєму продукує вислови, яким властиві формульний характер й універсальність загальної референції. Специфічні риси епохальності, знаковий характер притаманні й творчості Бориса Дмитровича Грінченка. Однією 3 них можна назвати високий ступінь афористичності мови митця. Афоризми Б. Д. Грінченка крізь призму спеціального лінгвокультурологічного дослідження не були вивчені, хоч увійшли як ілюстративний матеріал до окремих афористичних зібрань.

Мета статті полягає в розкритті семіотики i прагматики афористики Бориса Дмитровича Грінченка. Відповідно передбачено розв'язання таких завдань: 1) дослідити семантичну будову афористичних висловів 3 ідіолекта Б. Д. Грінченка; 2) з’ясувати лінгвостилістичний аспект афористики видатного україніста.

Афористика $є$ предметом наукового вивчення в українському й зарубіжному мовознавстві 3 позицій функціонування переважно в художньому, мас-медійному, політичному й епістолярному дискурсах (М. А. Алексєєнко, С. Г. Гаврін, В. В. Жайворонок, С. Є. Іванов, В. С. Калашник, А. В. Королькова, Т. І. Манякіна, М. А. Черкаський, О. І. Шейгал та ін.).

Під афоризмом розуміємо логічне, образне судження узагальнювального характеру, що в категоріях раціональності чи парадоксальності відбиває навколишній світ і виступає еквівалентом предикативної структури: Носиш сили в душі молодії, - Не зрікайся завчасно надії (2, с. 25); В порожньому житті немає втіхи (2, с. 33); Кожен чоловік помиляється (2, с. 432).

Афористичний вислів ідентифікуємо як інтелектуальний мовний знак, що належить до розряду синтетичних семіотичних знаків із 
прямою мотивацією та якому властивий комплекс диференційних ознак. Йому властиві автономний текстовий статус, неодноразовість відтворення в мовленні і входження до національної когнітивної бази.

Афористика Б. Грінченка цікава передусім тим, що за своїм семантичним розмаїттям охоплює майже всю велегранну спадщину митця - художню творчість (поезію, прозу, драматичні твори), переклади, публіцистику й епістолярій, лінгвістичні розвідки, науково-популярні тексти, історико-літературознавчі й літературнокритичні статті, рецензії, фольклористичні й етнографічні збірники [3], історико-педагогічні й теоретичні праці про освіту, школу, з теорії виховання та словника української мови - «мовної скарбниці українського народу» (О.О. Тараненко), де «з синівською сумлінністю, з дивовижною повнотою зібрано все, що на той час вродило квітчасте поле української мови» (О.Т.Гончар). У мовознавчих студіях «Наша літературна мова» Іван Огієнко (митрополит Іларіон) дав високу, авторитетну оцінку і найвагомішій лексикографічній праці Б. Д. Грінченка, назвавши Словник «відомим», значущість якого не викликає сумнівів і через століття, бо вже на той час правопис Словника «був прийнятий по всіх українських редакціях і виданнях» [7, с. 348], і самому укладачеві, адже він «знаний наш письменник» [там же].

Індивідуально-авторські афоризми українських майстрів слова попередньої літературної епохи й народні вислови були активно використані як ілюстративний матеріал у кожному томі «Словаря української мови» Б. Д. Грінченка. Наприклад:

«Амбо́н, на и ну, м. и амбо́на, ни, ж. Амвонъ. Поучали $c$ церковної амбони рідних братів чужою мовою. К. ХП. 122» $(3$, с. 7$)$ та «Тріво́га, ги, ж. Тревога, смятеніе. ... Закипіла по Вкраӥні страшенна трівога. К. Досв. 13» (6, с. 284) - афоризми зі збірок Пантелеймона Куліша «Хуторна поезія» (Л., 1882 р.) і «Досвітки. Думи и поэми» (СПб, 1862 р.);

«Безла́ддя, дя, с. Безпорядокъ, разладъ, несогласіе, неурядиця, анархія... У товаристві лад, - усяк тому радіє; дурне безладдя лихо dic. Гліб. 4» $(3$, с. 41) - афористичний вислів із байок Леоніда Глібова (К., 1904 р.);

«Затяжи́ти, жу́, жи́ш, гл. Обременить, отяготить. Хліб в дорозі не затяжить. Ном. № 11378» (4, с. 112) та «Компа́нія, нії, ж. 1) Общество, компанія. Злі компанії $і$ доброго чоловіка зопсують. Ном. № 5982» (4, с. 276) - народні вислови зі збірки «Українські приказки, 
прислівъя и таке инше», укладеної М. Номисом (СПб, 1864 р.) та «Слово, ва, с. Слово... Матушине словие - щзо зімнєє сонце» $(6$, c. 152) - власне паремія зі збірки «Этнографическіе матеріалы, собранные въ Черниговской и сосьднихъ съ ней губерніяхъ» (Ч., 1896 р.), укладеної й підготовленої до друку самим Борисом Грінченком;

«Люби́ти, блю', биш, гл. Любить... Любіть ї̈, думу правди, козацькую славу, любіть ї̈. Шевч. 128» (4, с. 286) та «Пиша́тися, ша́юся, сшся, гл. ... 2) Красоваться. Ще на Украӥні веселі $і$ вольнії пишались села. Шевч. 242» (5, с. 155) - афоризми 3 «Кобзаря» Тараса Шевченка (СПб, 1867 р.);

«Попильнувати, ну́ю, сш, гл. 1) Позаботиться, постараться. Попильнуй під старість дому. Котл. Од. 492» (5, с. 327) - афоризм із твору «Ода до кн. Куракина» (К., Од., 1890 р.) тощо.

У передмові до «Словаря української мови» Б. Д. Грінченко пояснює, чому джерельною базою для відбору мовного матеріалу послужили народні (з відомих лексикографічних праць) й індивідуально-авторські вислови, та зазначає: «Лучшими же для нашей работь (виділення Б. Д. Грінченка - Н. Ш.) писателями мы считаемъ тъхъ, которые, болђе или менъе мастерски владъя словомъ, въ то же время черпали свой словесный матеріалъ непосредственно изъ народной ръчи. Къ такимъ мы относимъ болње старыхъ писателей: Котляревскаго, Гулака-Артемовскаго, Квитку, Макаровскаго, Шевченка, М. Вовчка, Г. Барвинокъ, Симонова и затьмъ П. Кулиша» $(3$, с. XXX).

До цієї когорти найкращих українських митців ми з упевненістю зараховуємо й самого укладача Словника, адже його філологічні спостереження над мовним матеріалом (i тут особливо варто зауважити щодо відбирання одиниць пареміології - афоризмів і власне паремій) багато в чому розкривають специфіку власної мовотворчості, і продукування афоризмів зокрема. А це, справді, засвідчує «копітку шахтарську роботу над пошуком слова» (В. В. Яременко).

Афоризми створюють «документальну оповідь про життя, творчість, моральне і естетичне кредо Бориса Грінченка, розкривають його суспільно-політичний та мистецький ідеал, педагогічні погляди, вводять у коло його сучасників, дають уявлення про зміст їхніх оцінок» [10, с. 5]. Б. Д. Грінченко обстоює нерозривність понять «нація» - «культура» - «мова», розглядаючи складники цієї тріади як 
найважливіші ознаки суспільного буття, власне, перетин мовного й національного кодів. Це стало пріоритетним у мовотворчості митця, «що еволюціонувала, набувала поліфункціонального вияву в період поширення демократичних ідей, змін у класовому розшаруванні суспільства, дії загальноєвропейського процесу розвитку культури, пошуку платформ щодо подальших шляхів української нації та їі літературної мови» [6, с. 248].

Націоцентрична спрямованість поглядів митця пояснюється потребою об'єднання української нації, іiі добробутом. Це актуалізовано в низці афористичних висловів: Сьогодні не треба нам ні гніватися, ні битися, а брататися треба (2, с. 433); Але ж мусиш те щастя придбати на роботі для рідної хати (2, с. 25), де в етнокультурному образі рідна хата закодовано значно глибші смисли. Для Бориса Грінченка це Україна. Вербалізація етноконцепту «Україна» здійснюється в чотири етапи: 1) співвіднесення концепту 3 етимоном відповідного слова; 2) формування внутрішньої форми смислового центру концепту-образу; 3) символізація значення; 4) міфологізація концепту як дія символу в парадигмі культури (М. Ф. Алефіренко).

Семантичне становлення афоризмів, де транслюється національний код, починається 3 метафоричного переосмислення реальної дійсності, унаслідок чого лексичні компоненти деактуалізуються, прирощують конотацію, яка відтворює зв'язок асоціативно-образного підгрунтя 3 культурою, пї еталонами, символами і стереотипами (В. А. Маслова) і розглядається як знання, джерело когнітивного освоєння і Всесвіту загалом, і українського світу зокрема. Порівняємо 3 висловами із педагогічних розвідок Бориса Грінченка, наприклад Денащііоналізація веде до деморалізації уже сама собою [цит. за 10, с. 14], а також із афоризмами 3 епістолярної спадщини письменника - з листів до сестер Аполлінарії та Анни, написаних у 1891-1893 роках: Только работая для Украинь, мы можем иметь право на имя честных деятелей [там же, с. 13]. Відтак актуалізація національного духовного макроконцепту «Україна», який тлумачиться як складова культурного симболарію (Г. В. Токарев), визначає індивідуально-авторське когнітивне осмислення українського соціуму, всієї картини світу та має вплив на фонові знання комунікантів на рівні етносвідомості.

Визначальним в афористиці Бориса Грінченка $є$ осмислення національної зради як вияв громадянської позиції та поглядів не 
тільки самого автора, а й узагальненої думки його часу про запроданства, зрештою, досвіду багатьох поколінь: Кинути роботу для рідного краю $і$ піти на роботу до його гнобителів... єсть справжньою цілковитою зрадою (1, с. 194); Вами предки торгували, а продавши, породили вас на світ рабами (7, с. 70); Не пишайтеся козацьким родом: ви раби, хоча й пани ви над своӥм народом (7, с. 70).

Ставлення до свого громадянського обов'язку патріота й борця за національне й духовне відродження України знайшли вияв у афоризмах, де подано тверді переконання Б. Д. Грінченка у правильності обраної ідеї. Перш за все, вболівання за долю нації у вислові-переспіві національного символу українців: Ще не вмерла Україна, але може вмерти (7, с. 70). Крім того, це відбито у висловах iз семантикою упевненості у власних силах на визначеному шляху: Наша ідея велика людям світитиме всім, як і сіяла - довіку! (2, с. 26); Стане нам сили пройти шлях наш, тернами покритий, і щзб до краю знести всякі пригоди на світі (2, с. 26) чи то віри та сподівання: Колись і ти, сівачу правди й волі, на рідний степ повинен ще прийти (2, с. 32); Все прокинеться приспане, і воскресне пишний день праці, щзастя і пісень (2, с. 45) тощо.

Для Грінченкового афоризму характерна стереотипність світобачення й світовідчуття, крізь призму афоризмів письменник подає вичерпну характеристику українського суспільства на зламі століть: Не гордуй ти життям молодим, не журись безнадійно над їм (2, с. 25); Хто сіє сльози, сліз і сам зазна (1, с. 505); Тяжко без світу! (2, с. 411). Переосмислення семантики афористичних висловів, в основі яких лежать знаки-символи на позначення суспільнополітичних, правових, морально-етичних й естетичних цінностей, відбувається з урахуванням мовних ефектів, зокрема поєднанням у семантичній будові афоризму раціонального й образного (експресивного, емотивного): Народ-герой героїв появляє, шануючи, він їх вінцем вінчає (2, с. 47); Коли хочеш ти добро робити, - поспішай його робити швидше, поки є його чинити сила (2, с. 48) тощо.

Під творчим мікроскопом митця постає сучасне йому буття, репрезентуючи різні естетичні моделі, що водночас дозволяє відобразити власну життєву концепцію. Основу їі становить праця як визначальний мотив й умова суспільної позиції. Цей концепт широко представлено в афористиці Б. Грінченка 3 розгортанням у низку фреймів: «праця - сенс людського життя»: Треба робити іï, пращю, надбану віками, та не похилимось ми - буде надія із нами (2, с. 26), 
«праця - джерело і рушій суспільного розвитку»: Ще не родилися ми гори роботи лежали (2, с. 26), «праця - суспільна боротьба»: Працюй, борись, аж поки буде сила, і всіх людей до праџі закликай (2, с. 33), «праця - любов»: Тільки ідея не згине праці й любові до всіх! (2, с. 26).

У передмові до двотомного видання творів Бориса Грінченка Н. В. Левчик зазначає, що праця в його поетичній творчості «за значущістю дорівнюється до таких світових символів, як Краса й Любов» (2, с. 15). Показовим є той факт, що індивідуально-авторські вислови не просто транслюють філософські роздуми митця про працю як умову й вічну потребу людського існування (Моя пісня - то мій робітничий одпочинок $i$ моя робітницька молитва - надія [3, с. V-VI]), а набувають соціально-громадянського звучання, стають закликами й гаслами: Встань до пращуі повний сили $і$ надіï (2, с. 29); Сміливо, браття, до праичі ставайте! Час наступає - ходім! (7, с. 70); Праця єдина з недолі нас вирве - нумо до пращі, брати! (7, с. 70) тощо. Підгрунтя дієво-раціонального осмислення дійсності становить моральна й естетична оцінка людини-трударя, зокрема: Дяка і шана робітникам щирим, сором недбалим усім (7, с. 70); Без роботи погано рукам! (2, с. 26).

Відображення мовної картини світу й позамовної дійсності відбувається в афористиці митця крізь призму антропоцентризму, який «передбачає передусім особистість, одиничну або колективну, як одиницю свідомості. Індивід можна розглядати як одну свідомість, або свідомість одного, спрямовану на пізнання людиною оточення, в якому вона живе. Найближчим оточенням $\epsilon$, звичайно, етнос, колективна свідомість» $[4$, с. 64]. У передмові до збірки своїх поетичних творів Б. Д. Грінченко наголосив, що «кожна тут річ має в собі частинку мого я» [3, с. V].

За Грінченковим «я» («моє») в афоризмах завжди стоїть узагальнене «ми / ви» («наме»), а граматичні форми першої особи однини іменника позначені семантикою генералізації: $\boldsymbol{Я}$ люблю просто до загину рідну мову та пісні, матір-Украӥну (7, с. 70); Нехай моя присяга буде вашою! (2, с. 411); Нічого не звелю, - тільки не забудьте мого заповіту! (2, с. 412); Добувайтеся правди! (2, с. 411). Мовні одиниці засвідчують: у колективному світогляді $є$ Правда i Праця як найвищі цінності суспільства, а в центрі особистісного світосприйняття - перебіг складних процесів формування індивідуального й етнічного «я»: «Звідси етногенез, або становлення етнічного «я» у всесвітньому контексті» [4, с. 64]. 
Моральні цінності й етичні ідеали самого автора визначають суспільну духовність, підносячи на найвищі щаблі його світовідчуття й світорозуміння: Наша доля - іти серед темряви $і$ страшних хуртовин (7, с. 70); Моє життя - самотня тиха прачя (2, с. 39); До Сонця генія високого рівняю $(1$, с. 89$)$. Наведені афоризми сприймаємо як громадянське кредо Бориса Грінченка, де в атмосфері духовного й фізичного поневолення України висунуто маніфест боротьби за основні цінності буття - свободу, життя, працю, дух, щастя, правду, добро: Боротися $і$ працюювати, щьоб нам добути волі; Зло від своїх найтяжче уражає; Багато $\epsilon$ людей, нема людей-братів (Б. Д. Грінченко).

Мовні особливості афористики реалізовані також і за допомогою структурної організації афористичного вислову. Так, у поетичному доробку митця багато афоризмів, які функціонують на базі риторичних й окличних речень на позначення позиції автора щодо дійсності на зразок: Навіщо ж ви на світі живете, коли на серие єсть у вас-крижина? Нащу ж людями ви себе звете, коли забули, щчо таке лю г и н а ?! (2, с. 28).

Афоризми, у яких позиція автора щодо висловлюваного характеризується високим ступенем референції, розглядається нами як утворення активної структури, побудова яких супроводжується низкою маркерів суб' єктивної модальності, зокрема:

1) синтаксичними: інтонацією (окличною, питальною), як-от: I світ воскрес! (2, с. 32); Добре поезї на світі жити! (2, с. 35); звертаннями: Природо-мати! кожен з нас змарнілих, життям важким натомлених та хворих, намучивиись усім, щзо серце й душу вражає глибоко, - до тебе йде (2, с. 33);

2) морфологічними, а саме займенниками чи займенниковими прислівниками: На що тоді ввесь цей лад [7, с. 241] або частками Тільки де вже раз життя устало, там росте воно й буяє зараз (2, с. 108); Тільки смерть великих робить нас (1, с. 501);

3) стилістичними - конструкціями експресивного синтаксису): парцеляцією Людина я... I мушу червоніти із сорома, щุо маю зваться так! (2, с. 42);

- риторичним питанням-відповіддю на кшталт: Щастя хочеш ти зазнати? Щастя дурно не дається: тільки той його придбає, хто за його в бої б' сться (2, с. 47);

- прямою мовою: «Зроблю», - сього сахайся слова. «Зробив», оце потужних мова (2, с. 47); 
- інверсією: Як мала у тебе сила, то з гуртом єднайся ти вкупі більше зробиш діла, швидше дійдеш до мети (2, с. 45);

- лексичним повтором: Кожен чує, що живе на світі, кожен чує, як тепло злітає, $і$ усе, щз може оживати, - все вертає до життя нового (2, с. 108);

4) комплексом мовних засобів: Майте жс прапором, надї̈! (2, с. 45); Хочеш вік прожити марно ти? То малої добирай мети (2, с. 47); Хочеш вік прожить немарно ти? Вищої шукай собі мети (2, с. 47) тощо.

Афоризми, що репрезентують нейтральну позицію автора щодо висловлюваного, ми кваліфікуємо як утворення нейтральної структури: Краще кривду вже терпіти, ніж самим ї̈ чинити (2, с. 46); Як тебе вороги на хресті розіпнуть, то стогнання свого ти не дай їм почуть $(2$, c. 48$)$.

За умов посилання на іншого адресанта в афоризмі відсутня пряма референція, відповідно одиниці характеризуються низьким рівнем адресантної активності. Афоризми цього різновиду ми визначаємо як утворення пасивної структури, наприклад: $O m$, кажуть, - пригоди учать людей згоди (2, с. 46); Говорять люди: не зітхай, чого нема, то й так нехай $(2$, с. 46). Побудова грунтується на використанні вставних слів, словосполучень, речень, що мають семантику об'єктивного, авторитетного джерела повідомлення (відомо, кажуть, як кажуть, говорять люди).

Загальновідомо, що поетичні афоризми переважно мають форму диптиха - завершеної за смислом окремої строфи, яку складають два віршовані рядки; зрідка - у формі катрену, тобто семантично оформленої строфи з чотирьох рядків [9, с. 253].

Відповідно до усталеної афористичної традиції у мові творів Б. Д. Грінченка виокремлюємо різноманіття конструкцій, орієнтованих на продуктивні моделі мови. Низка висловів має таку структурну організацію:

1) за моделлю диптиху: Якщо праведне се діло буде, То ніщзо тут не злякає серия... (2, с. 25);

2) за моделлю катрену: Не гордуй ти життям молодим, Не сумуй безнадійно над їм I початки святої надії ти зневір'ям тяжким не дави, Вір у сили свої молоді (2, с. 25).

Національний світогляд якнайкраще відображають використані автором мовні одиниці, що репрезентують власне паремійний корпус: Час прийшов умирати (2, с. 411); Люди добрі (2, с. 433). Клішованість, 
афористичність і сентенційність у комплексі впливають на характер семіотичної й змістової структури паремійної мовної одиниці, у першу чергу - пї референційної складової і семантичної мотивації. В основі цілісного смислового змісту паремії лежить не власне дефініція, а міркування. Ужиті Б. Д. Грінченком народні вислови містять і виразно оцінні судження, які стосуються характеристики соціально значущих для українців ситуацій. Паремії співвідносяться із прецедентними феноменами (Д. Б. Гудков), що спираються на фонові знання комунікантів, визначають світ норми, закономірностей, узагальнень і стратегію моральної поведінки кожної людини й соціуму загалом. Паремії характеризується певним типом образної побудови, при якій відтворюється економно обрана конкретна ситуація з виділенням таких іiї сторін, що можуть стати узагальненою формою передачі думок. Використовуючи прислів'я в переносному значенні, митець подає афористичне віддзеркалення велегранності народного досвіду.

Низка паремійних одиниць (приказки, прислівно-приказкові вислови, побажання), які функціонують у мові творів Б. Д. Грінченка, почасти піддаються трансформації, як-от: Набрались бебехів тягти, а діло забули (2, с. 435); Та тебе люди заклюють (2, с. 411); Це не твоєі голови діло (2, с. 161) чи стилізації (А коли хочеш добре жити - роби, не пияч (2, с. 161); Спасибі тим рученькам, щзо мене носили-годували (2, с. 412). Порівняємо трансформовану паремію Якщо я брехню кажу, хай мене поб'є небесна сила! (2, с. 99) із зафіксованим у 4-му томі «Словаря української мови» народним висловом Щоб я вмер, коли неправду кажу зі збірки М. Номиса «Українські приказки, прислівъя и таке инше» (СПб, 1864 р.). Наведена мовна одиниця ілюструє одну зі словникових статей Словника: «Уміра́ти, а́ю, єш, сов. в. уме́рти, умру́, ре́ш, гл. Умирать, умереть. Коли вмірати, то вмірати, - то все треба день стеряти. Ном. № 4268. Хто за віру умірає, той собі царство заробляє. Ном. № 1. Щоб я вмер, коли неправду кажу. Ном. № 932. Хто вмер, той каятиметься, такой хорошій солнечный день. Ном. № 603» (6, с. 338).

У художніх текстах Бориса Грінченка активно побутують етикетні кліше на зразок Спасибі вам (2, с. 432); Хвалити Бога! (2, с. 432); Дай, Боже, вам здоров'я! (2, с. 432). Ритуальні словесні комплекси на позначення привітання, побажання, прощання, прохання, вибачення й застереження, використані героями в безпосередніх побутових ситуаціях, відображають цінності 
українського народу, які становлять основу певної світоглядної оцінки - позитивної чи негативної: Хай заплатить Бог тобі за ласку (2, с. 98).

Подібні стереотипні мовні одиниці ілюструють словникові статті у «Словарі української мови», наприклад: «Щасти́ти, ти́ть, гл. Давать, посылать, приносить счастье, благопріятствовать, удаваться. Употребляется безлично или въ третьемъ лицъ, преимущественно когда говорится о Богъ; также въ повелительн. наклоненіи ед. ч. въ выраж.: Щасти́, Боже! Хай Бог щастить. Ном. № 11368» (6, с. 523) етикетне кліше зі збірки М. Номиса «Українські приказки, прислівъя и таке инше» (СПб, 1864 р.).

Оскільки паремії $є$ загальнореферентними одиницями, то їхнім позначуваним виступає не якась одинична подія, а узагальнена типова мікроситуація. Кожне наступне використання паремії відсилає адресата до певної, конкретної ситуації, знаком-номінацією якої вона є. Художня виразність лінгвоодиниць досягається за допомогою спектра мовних засобів на позначення категорії узагальнення, що зближує народні та індивідуально-авторські вислови. Зокрема, варто зауважити про високу частотність використання в семантичній будові наведених вище паремій таких морфологічних засобів узагальнення, як уживання 2-ї особи в дієслівних формах (хочеш, не пияч), а в трансформованих висловах 3-ї особи дієслів (минулий час - набрались, забули, носили-годували; майбутній час - заклюють), специфічний вияв модальності (хвалити, дай, хай заплатить, хай поб'є, коли хочеш жити), використання різних за лексико-граматичним значенням займенників (тебе, мене, вам, тобі, я, твоєї, це, тим, щзо, твоєї голови у значенні твоє) й актуалізацію абстрактних (діло, небесна сила, брехню, здоров'я, ласку) або конкретних, у тому числі стилізованих (рученькам, люди) іменників. Актуалізація в наведених мовних фактах слів із протилежним значенням підкреслює протиставлення суб'єктів, дій, процесів, станів, відокремлення їх з-поміж інших: бебехів тягти діло забули, добре жити, роби - не пияч тощо. Реалізація категорії узагальнення в семантичній будові введених в художню мову паремій являє собою логіко-поняттєву й емотивну інтеріоризацію дійсності, розкриває національно-мовну картину світу. На рівні такого вжитку клішованих мовних одиниць відбувається утвердження етнічного морального кодексу українства й універсально-культурних кодів. 
Отже, ідіолект Б. Д. Грінченка, багатогранна природа його творчої свідомості найвиразніше розкриваються при осмисленні афористичної спадщини митця - багатогранного мовного масиву, що транслює винятковість автора і досвід цілого народу з актуалізацією основних ідеологем Україна, ідея, надія, праця, сила, людина, життя. Глибинна мудрість і сентенційність притаманні афористиці Бориса Грінченка, яка відображає його світогляд, художньо-естетичні пошуки i смаки, ідейне спрямування ідіостилю та репрезентує перетин національного й мовного кодів.

\section{Література}

1. Бацевич Ф. С. Словник термінів міжкультурної комунікації / Ф. С. Бацевич. К. : Довіра, 2007. -205 с.

2. Гриценко П. Ю. Ідіолект і текст / П. Ю. Гриценко // Лінгвостилістика : об’єкт стиль, мета - оцінка : зб. наук. праць, присвячений 70-річчю проф. С. Я. Єрмоленко / Відп. ред. акад. НАН України В. Г. Скляренко. - К., 2007. - С. 16-43.

3. Грінченко Б. Писання / Б. Д. Грінченко. - К., 1903. - Т. 1. - С. V-VI.

4. Жайворонок В. В. Мовні знаки української етнокультури в антропоцентричному висвітленні / В. В. Жайворонок // Мовознавство. - 2012. - № 2. - С. 58-64.

5. Калашник В. С. Українська поетична афористика як джерело естетичного сприймання основних життєвих цінностей / В. С. Калашник // Українська духовна культура в системі національної освіти : [тези доповідей та повідомлень]. - Х. : ХДУ, 1995. - C. 31-33.

6. Кравченко М. Поняття нації і культура в мові творів Бориса Грінченка / М. Кравченко // Етнос. Нація. Культура. - Дрогобич, 2001. - Вип. 2. - С. 248-253.

7. Огієнко Іван (митрополит Іларіон). Рідна мова / Іван Огієнко (митрополит Іларіон) ; упоряд., авт. Передмови та коментарів М. С. Тимошик. - К. : Наша культура і наука, 2010. $-436 \mathrm{c}$.

8. Українська афористика. - К. : Просвіта, 2001. - 320 с.

9. Федоренко Н. Т. Афористика / Н. Т. Федоренко, Л. И. Сокольская. - М. : Наука, 1990. $-416 \mathrm{c}$.

10. Яременко В. В. «За право тільки жить...». Борис Грінченко : факти і документи / В. В. Яременко // Грінченко Б. Д. До тих, що зостануться : Вибрані твори / Упроряд., передм. та приміт. В В. Яременка. - К. : Веселка, 1993. - С. 5-34.

\section{Використані джерела}

1. Антологія афоризмів /Упор. Л. П. Олексієнко. - Донецьк : Сталкер, 2004. - 704 с.

2. Грінченко Б. Д. Вибрані твори в 2-х т. : Т. 1 / Борис Дмитрович Грінченко ; упоряд. Ю. Б. Кузнєцов, Н. В. Левчик ; вступ. ст. Н. В. Левчик. - К. : ІНТЕЛЕКТ-АРТ, 2008. $-448 \mathrm{c}$.

3. Словарь української мови : у 4-х т. / Упроряд., $з$ додатком власного матеріялу, Борис Грінченко. - Т. 1. А - Ж. - Репринт. вид. Кіевъ, 1907. - К. : Лексикон, 1996. - 496 с.

4. Словарь української мови : у 4-х т. / Упроряд., 3 додатком власного матеріялу, Борис Грінченко. - Т. 2.3 - Н. - Репринт. вид. Кіевъ, 1908. - К. : Лексикон, 1996. - 578 с.

5. Словарь української мови : у 4-х т. / Упроряд., $з$ додатком власного матеріялу, Борис Грінченко. - Т. 3. О - П. - Репринт. вид. Кіевъ, 1909. - К. : Лексикон, 1996. - 507 с. 
6. Словарь української мови : у 4-х т. / Упроряд., з додатком власного матеріялу, Борис Грінченко. - Т. 1. Р - Я. - Репринт. вид. Кіевъ, 1909. - К. : Лексикон, 1996. - 566 с.

7. Степанишин Б. І. Українська поетична афористика минулого тисячоліття / Б. І. Степанишин. - Тернопіль : Підручники і посібники, 2004. - 208 с. 